\title{
1 Reassessing Escherichia coli as a cell factory for biofuel production
}

2 Chonglong Wang ${ }^{\mathrm{a}}$, Brian F. Pfleger ${ }^{\mathrm{b}, \mathrm{c}^{*}}$ and Seon-Won Kim ${ }^{\mathrm{d} * *}$

3 a School of Biology and Basic Medical Sciences, Soochow University, Suzhou, People's Republic of

4 China

$5{ }^{\mathrm{b}}$ Department of Chemical and Biological Engineering, University of Wisconsin-Madison, Madison,

6 Wisconsin, USA

$7{ }^{\mathrm{c}}$ Microbiology Doctoral Training Program, University of Wisconsin-Madison, Madison, Wisconsin,

$8 \quad$ USA

9 d Division of Applied Life Science (BK21 Plus), PMBBRC, Institute of Agriculture and Life Sciences,

10 Gyeongsang National University, Jinju, Republic of Korea

11 *Corresponding address: 1415 Engineering Drive, Madison, WI 53706; E-mail:

12 brian.pfleger@wisc.edu

$13 * *$ Corresponding address: 501 Jinju-daero, Jinju 52828, Republic of Korea; E-mail:

14 swkim@gnu.ac.kr

15 


\section{Abstract}

17 Via metabolic engineering, industrial microorganisms have the potential to convert renewable

18 substrates into a wide range of biofuels that can address energy security and environmental

19 challenges associated with current fossil fuels. The user-friendly bacterium, Escherichia coli,

20 remains one of the most frequently used hosts for demonstrating production of biofuel

21 candidates including alcohol-, fatty acid- and terpenoid-based biofuels. In this review, we

22 summarize the metabolic pathways for synthesis of these biofuels and assess enabling

23 technologies that assist in regulating biofuel synthesis pathways and rapidly assembling novel

24 E. coli strains. These advances maintain E. coli's position as a prominent host for developing

25 cell factories for biofuel production. 


\section{Introduction}

28 The development of biofuel-producing microbes is motivated by a desire to find sustainable

29 alternatives to fossil fuels and to reduce the net amount of greenhouse gases released through

30 the combustion of transportation fuels [1,2]. Microbial metabolism has evolved to comprise

31 pathways for synthesizing a variety of metabolites with fuel-compatible properties including

32 linear, branched and cyclic alcohols, alkanes, alkenes, esters and aromatics. Microbes isolated

33 from environmental samples often possess these metabolic pathways for biofuel synthesis

34 [3,4]; however, they rarely synthesize biofuels in the elevated quantities needed for

35 economically-viable processes. That said, there exist several natural isolates that produce

relevant quantities of fuels, e.g. efficient fermentation of sugar to ethanol by yeast or to

butanol by Clostridium species [5], but the probability of identifying a natural isolate capable of producing other advanced biofuels is infinitesimally small. Furthermore, natural hosts rarely possess the complete suite of traits required for commercial biofuel production.

40 Engineering native isolates into robust workhorses often requires overcoming limitations such as low growth rates, limited catabolic capabilities, poor tolerance to substrates, products, and desirable environmental conditions. For this reason, the alternative approach of engineering a model, genetically-tractable host is a common strategy for accessing the repertoire of natural and synthetic biofuel-producing pathways.

With the advent of recombinant DNA technology, harnessing a user-friendly microorganism such as Escherichia coli for biofuel production could be an attractive alternative to the natural isolates [6-8]. E. coli as a host has several advantages over other industrial microbes for biofuel production (Table 1). The advantages are as follows: i) both aerobic and anaerobic growth using various carbon sources in defined salt media; ii) possession of high growth and metabolic rates; iii) a vast knowledgebase of genetic, metabolic and physiological traits; and 
iv) a plethora of genetic tools available for performing metabolic engineering. These benefits encourage metabolic engineers to construct novel pathways to synthesize desired biofuel products in the genetically tractable E. coli host. Enormous genomic sequences have been disclosed for new metabolic reactions and are available in public databases, which provides a wealth of gene variants to construct novel and efficient pathways for biofuels production in $E$. coli. In fact, several biofuel candidates with great potential to replace traditional fuels have been investigated for production in E. coli over the past two decades. Such an engineering process relies on introduction of one or more genes encoding the enzymes of the pathway, which are orchestrated by tools of systems biology, metabolic engineering, and synthetic biology to effectively convert intracellular metabolites into the target products $[9,10]$. The pathway enzymes therefore need to be expressed in $E$. coli at a level that provides sufficient pathway activity but prevents wasteful usage of cellular resources needed elsewhere in metabolism. Similar engineering efforts are required to optimize the expression of genes that encode other critical traits, e.g. product tolerance, without reducing flux to biofuel or 65 depleting cellular resources.

Therefore, the essences in development of E. coli as a cell factory for biofuel production are the construction of novel biosynthesis pathways, the sophisticated regulation of pathways and cellular metabolism, and the manipulation of host tolerance to biofuel products. Other aspects including breakdown of biomass into usable carbohydrates are beyond the scope of this review and have been discussed elsewhere $[11,12]$. In this review, we will mainly assess the recent metabolic engineering achievements and enabling technologies, and highlight their great application potential to realize overproduction of biofuels in E. coli in the future. 
74 Pioneering work on the metabolic engineering for biofuels could be traced back to the import

75 of the ethanologenic pathway of Zymomonas mobilis into E. coli [13]. Heterologous expression of pyruvate decarboxylase and alcohol dehydrogenase results in conversion of pyruvate to ethanol in E. coli. However, ethanol as the first generation biofuel has lower energy density of around $30 \%$ than gasoline, and is incompatible with current fuel infrastructure owing to its highly hygroscopic and corrosive drawbacks $[14,15]$. To circumvent this problem, many ingenious biosynthesis pathways have been developed in $E$. coli to generate a variety of fuel-like molecules from the general metabolites (Fig. 1) [16,17]. Collectively, these Biofuel candidates can be categorized into three types: alcohol-derived (larger than two-carbon), fatty acid-derived, and terpenoid-derived biofuels.

One of the most recognized and promising biofuel candidates is 1-butanol, which is naturally produced from some Clostridium species (e.g. C. acetobutylium) via the typical acetonebutanol-ethanol (ABE) fermentation pathway $[5,18]$. The fermentative butanol synthesis is initiated with acetyl-CoAs, which are catalyzed consecutively by thiolase, 3-hydroxylbutyrylCoA dehydrogenase, crotonase and butyryl-CoA dehydrogenase for synthesis of butyryl-CoA, and finally converted to 1-butanol by aldehyde/alcohol dehydrogenase. This pathway has been reconstructed in $E$. coli by several research groups for non-native production of butanol [19-21]. Amino acid metabolism leads to the synthesis of many interesting small organic acids including $\alpha$-ketoacids that can be converted to alcohols with promising fuel properties. Production of $\mathrm{C}_{3}-\mathrm{C}_{5}$ alcohols was demonstrated in E. coli using the Ehrlich degradation pathway from yeast; the pathway consists of a promiscuous decarboxylase converting $\alpha$ ketoacids to aldehydes and a dehydrogenase converting aldehydes to alcohols [22]. Alcohol mixtures including propanol, butanol, isobutanol, and amyl alcohols were produced from the amino acid precursors of various $\alpha$-ketoacids in E. coli [23]. Engineering of enzymes 
involved in leucine synthesis pathway enabled recursive elongation of $\alpha$-ketobutyrate into long-chain $\alpha$-ketoacids, and resulted in production of longer chain $\left(\mathrm{C}_{5}-\mathrm{C}_{8}\right)$ alcohols including

100 pentanol, hexanol, 3-methyl-1-pentanol, 4-methyl-1-pentanol, 4-methyl-1-hexanol and 5101 methyl-1-heptanol [24,25]. In addition, overexpression of O-acyltransferase allowed the 102 recombinant E. coli to produce various acetate esters using acetyl-CoA as an acyl donor [26].

103 Other types of esters such as butyrate and isobutyrate esters could be also produced by combination of diverse acyl-CoA synthesis with alcohols production. In addition to serving as a demonstration host for the function of biofuel pathways, E. coli has been successfully engineered to increase the performance (TRY: titer, rate, and yield) of alcohol (1-propanol,

107 isopropanol, 1-butanol, isobutanol, etc.) production beyond other species (Table 1).

108 Engineered E. coli strains produced isopropanol of $143 \mathrm{~g} / \mathrm{L}, 1$-butanol of $30 \mathrm{~g} / \mathrm{L}$, and 109 isobutanol of $50.9 \mathrm{~g} / \mathrm{L}$, respectively [27-29]. C. acetobutylicum as a native butanol producer 110 produced 1-butanol up to $130 \mathrm{~g} / \mathrm{L}$ [30], but failed in the production of other higher alcohols.

111 Saccharomyces cerevisiae was engineered to produce isobutanol at a titer of $1.62 \mathrm{~g} / \mathrm{L}$ only

112 [31]. Corynebacterium glutamicum, a well-known amino acid producer, was also engineered

113 to produce isobutanol based on its effective L-valine synthesis pathway. The productivity 114 obtained from the engineered $C$. glutamicum is $13 \mathrm{~g} / \mathrm{L}$ of titer, $0.32 \mathrm{~g} / \mathrm{L} / \mathrm{h}$ of rate, and $0.20 \mathrm{~g} / \mathrm{g}$ 115 glucose of yield, which is however much lower than the productivity (titer, $50.9 \mathrm{~g} / \mathrm{L}$; rate, $1160.70 \mathrm{~g} / \mathrm{L} / \mathrm{h}$; and yield, $0.29 \mathrm{~g} / \mathrm{g}$ glucose) obtained from an engineered E. coli [27,32]. Bacillus 117 subtilis was made to produce butanol and isobutanol albeit a quiet low in titer [21,33], but the 118 conversion of protein waste to biofuels was a benefit of using B. subtilis [34].

119 Fatty acids are natural precursors to many classes of compounds found in current fuels (e.g. 120 alcohols, alkanes, and esters) but are more commonly thought of as the main component of 121 naturally occurring lipids, such as phosphoglycerides of cell membrane constituents and 
122 triglycerides of energy storage materials. Biosynthesis of fatty acids is an iterative carbon123 chain elongation process using acetyl-CoA as a primer, and malonyl-CoA or methylmalonyl-

124 CoA as extending molecules by type I fatty acid synthase (FAS) in animals and fungi, or type

125 II FAS in most bacteria. Fatty acids can be converted to fatty acid esters by promiscuous 126 acyltransferases, to fatty alcohols by reductase and alkanes by decarboxylases [35-38]. For 127 example, the aldehyde reductase $\mathrm{YbbO}$ of $E$. coli has been re-illuminated to reduce fatty 128 aldehyde to fatty alcohol production [38]. The major concern for fatty acid-derived biofuels in terms of fuel properties is to synthesize various fatty acids with different chain lengths or 130 branched chains that alter their physical properties (e.g. cloud point). Chain length can be 131 controlled by thioesterases expressed in many bacteria and plants and the introduction of 132 these thioesterases in E. coli enabled production of fatty acids with different chain lengths 133 [39,40]. The 1,4-dihydroxy-2-naphthoyl-CoA thioesterase YdiI of E. coli could function as a cycle-terminating enzymes to hydrolyze acyl-CoAs and produce corresponding short- and medium-chain $\alpha, \beta$-unsaturated carboxylic acids [41]. The unexpected role of YdiI could be assessed in $E$. coli with an engineered reversal of the $\beta$-oxidation. Replacement of a straight 137 chain acyl-CoA-specific $\beta$-ketoacyl-ACP synthase (straight FabH) with a branched-chainacyl-CoA-specific homolog (branch FabH) led to the synthesis of branched chain fatty acids [42]. Complete lipoylation of 2-oxoacid dehydrogenase by engineering of protein lipoylation pathways increased the percentage of the branched chain fatty acids to $77 \%$ of total fatty acid

141 production [43]. The fatty acid $\beta$-oxidation cycle was reversed to increase the carbon and 142 energy efficiency of acyl-CoAs synthesis by using acetyl-CoA instead of malonyl-CoA for the acyl-chain elongation, which resulted in higher production of fatty alcohols [44]. E. coli

144 and S. cerevisiae have been engineered to produce fatty alcohols and fatty alkanes, albeit 145 relatively low in the production titers due to a low efficiency of the relevant enzymes. E. coli 146 produced $1.95 \mathrm{~g} / \mathrm{L}$ fatty alcohols and $0.58 \mathrm{~g} / \mathrm{L}$ fatty alkanes $[45,46]$, whereas $S$. cerevisiae 
147 produced $1.1 \mathrm{~g} / \mathrm{L}$ of fatty alcohols and $0.1 \mathrm{~g} / \mathrm{L}$ of fatty alkanes, respectively [47,48]. E. coli

148 was superior to $S$. cerevisiae in production of both fatty alcohols and alkanes. Oleaginous

149 microorganisms such as Yarrowia lipolytica, which are likely to accumulate lipids in a high

150 content, can be a good host for production of fatty acid-derived biofuels (Table 1) [49,50]. An

151 engineered $Y$. lipolytica expressing acetyl-CoA carboxylase (ACC) and diacylglycerol

152 acyltransferase (DGAT) presented the overall yield of $0.195 \mathrm{~g}$ lipids $/ \mathrm{g}$ glucose, an equivalent

153 to $61 \%$ of the theoretical maximum yield [51]. The further overexpression of $\Delta-9$ stearoyl-

154 CoA desaturase (SCD) improved the production yield to $0.234 \mathrm{~g} / \mathrm{g}$ glucose ( $85 \%$ of the

155 theoretical maximum yield) [52]. However, metabolic engineering of $Y$. lipolytica for fatty

156 acid-derived biofuels is still in its infancy and remains to be developed by more studies [53-

$15756]$.

158 Terpenoids are a large family of natural products with great pharmaceutical and nutritional

159 interests. They have been also considered as ideal drop-in biofuel molecules because of their

160 long chain hydrocarbon structure. Biosynthesis of terpenoids is initiated from two universal

$161 \mathrm{C}_{5}$ units, isopentenyl diphosphate (IPP) and dimethylallyl diphosphate (DMAPP), which can

162 be condensed by a head-to-tail manner into a series of isoprenyl diphosphate: geranyl

163 diphosphate $\left(\mathrm{GPP}, \mathrm{C}_{10}\right.$ ), farnesyl diphosphate (FPP, $\mathrm{C}_{15}$ ) and geranylgeranyl diphosphate

164 (GGPP, $\mathrm{C}_{20}$ ). Metabolic engineering of mevalonate (MVA) pathway and 2-C-methyl-D-

165 erythritol 4-phosphate (MEP) pathway for the synthesis of IPP and DMAPP has been

166 reviewed elsewhere [57,58]. Terpenoids with simple olefins structure render promising

167 physical and chemical traits as biofuels, which can be produced by simple dephosphorylation

168 of the isoprenyl diphosphate such as IPP, DMAPP, GPP and FPP. As terpene synthases and

169 phosphatases mediating the dephosphorylation serve a critical role in production of

170 terpenoid-derived biofuels, a challenge is to secure an appropriate enzyme from either plants 
171 or bacteria converting isoprenyl diphosphates to terpenoid biofuels. Production of 172 isopentenols was reported only from E. coli. Screening of Bacillus subtilis genomic DNA 173 library revealed the Nudix hydrolase NudF hydrolyzing DMAPP and IPP to prenol and 174 isoprenol [59], which are collectively called isopentenols. The investigation of Nudix 175 (Nucleoside diphosphate linked to $\underline{X}$ ) family members from E. coli demonstrated another 176 good candidate, Nudix hydrolase NudB [60]. Both NudF and NudB have been used for 177 isopentenol production in E. coli, and $2.23 \mathrm{~g} / \mathrm{L}$ of isopentenol (70\% of apparent theoretical 178 yield) was produced in the engineered E. coli overexpressing NudB [61,62]. E. coli 179 undecaprenyl diphosphate phosphatases, $\mathrm{YbjG}$ and $\mathrm{PgpB}$, have been recently identified to 180 hydrolyze FPP to farnesol, and successfully applied for farnesol production of $526.1 \mathrm{mg} / \mathrm{L}$ in 181 a shake flask [63], which was significantly higher than the farnesol production (145.7 $\mathrm{mg} / \mathrm{L})$ 182 of $S$. cerevisiae in a bioreactor [64]. Thus, some promiscuous phosphatases have been re183 evaluated as important participants in production of terpenoid alcohols. To date, the advances 184 in engineering of terpene synthases have also proceeded production of pinene, geraniol, 185 limonene, farnesene and bisabolene [65-69], although the reported production titers have 186 been limited at a scale of $\mathrm{mg} / \mathrm{L}$ in a shake flask culture. Terpenoid molecules are promising 187 alternatives to diesel and jet fuels due to their branched hydrocarbon chains and various ring 188 structures, which lower their freezing temperature [68]. However, production of these 189 molecules has required significant effort and successful demonstrations are being reported 190 (e.g. isoprene $\left(\mathrm{C}_{5}\right.$, hemiterpene) production in $E$. coli and farnesene $\left(\mathrm{C}_{15}\right.$, sesquiterpene) 191 production in $S$. cerevisiae) [70,71]. By optimizing fermentation conditions, an engineered $E$. 192 coli strain produced more than $60 \mathrm{~g} / \mathrm{L}$ of isoprene with volumetric productivity of $2 \mathrm{~g} / \mathrm{L} / \mathrm{h}$, 193 and an engineered S. cerevisiae produced more than $100 \mathrm{~g} / \mathrm{L}$ of farnesene with volumetric 194 productivity of up to $2.24 \mathrm{~g} / \mathrm{L} / \mathrm{h}$ in a bioreactor. The significant production of isoprene and 
195 farnesene encourages us to improve productivity of terpenoid biofuels by a creative 196 engineering of host strains and a fermentation optimization in bioreactor.

\section{New enabling technologies for biofuel production in $E$. coli}

198 To build a synthetic metabolic pathway in $c$ one typically collects genes from various

199 organisms and combines them with gene expression signals (e.g. promoter, terminator,

200 ribosome binding site - RBS) in expression vectors. Genes are often selected based on their

201 performance in their native host or in in vitro assays. Transplantation of genes between hosts

202 is not always able to recapitulate these advantages. The performance of the heterologous

203 pathway can suffer from incorrect or poor expression of proteins, promiscuous activity of

204 enzymes on substrates not found in the native host, accumulation of toxic intermediates, and

205 cross-talk with native host metabolism. Subcellular localization of certain eukaryotic enzymes of terpenes synthesis is also a challenge in their implementation in E. coli owing to lack of organelles in the host. For these reasons, metabolic engineers have developed a wide array of tools for optimizing functional expression of heterologous pathways. Common approaches include re-coding of genes to optimize codon usage, overexpression of rate-

210 determining enzymes, titrating gene expression with plasmid copy number, promoter strength

211 and RBS strength, and screening combinatorial libraries of genes and control elements

212 [72,73]. In addition, numerous synthetic biology techniques have been developed to enhance

213 the rate of strain construction and to increase the complexity of gene regulation $[74,75]$.

214 The bacteria adaptive immunity system CRISPR (clustered, regularly interspaced, short

215 palindromic repeats) technology provides a powerful genetic tool for genome editing and 216 gene silencing [76,77]. The endonuclease Cas9 with guide RNA (gRNA) can specifically 217 recognizes and cleaves target DNAs, which facilitates generation of mutations, deletions or insertions for engineering of host strain (Fig. 2a). A large DNA fragment encoding an 
219 isobutanol synthesis pathway was effectively integrated into E. coli genome by using a 220 Cas9/CRISPR-based one-step approach [78]. A Cas9 mutant, which has lost the endonuclease activity, has been used to block transcriptions through its binding to target genes, which allows a simultaneous repression of multiple genes by using multiple gRNAs (Fig. 2a). Such a CRISPR interference (CRISPRi) technology was used to repress the transcription factor

224 FadR, which resulted in an increase in fatty acid synthesis and a reduction in $\beta$-oxidation in $E$. coli [79]. Kim et al used the same approach to regulate a heterologous MVA pathway for production of bisabolol as well as to repress a chromosomal ispA gene for production of isoprene [80]. Antisense RNAs (asRNAs), which are able to complementarily bind to 5'untranslated region (5'-UTR) of their cognate transcripts, have been created and applied for precise control of gene expression [81]. The tailored asRNAs targeting $f a b B$ and $f a b F$ effectively repressed malonyl-CoA synthesis in E. coli [82]. Small regulatory RNAs (sRNAs) can also target their complementary mRNAs, which recruits host factor Hfq and subsequently induce the mRNA degradation [83]. Inspired from this, artificial sRNAs have been designed with the predictable repression efficiency to improve production of tyrosine and 1,3diamimopropane $[84,85]$.

Prokaryotic E. coli allows expression of a synthetic pathway in a single operon, which is convenient for transcriptional control of multi-genes, but ineffective for modulation of expression level of each gene independently. The expression level of each gene in an operon can be modulated by rational design of the ribosomal binding site (RBS) to have a desired translational initiation rate (TIR). In silico program is available to guide the RBS design [86], which has been validated in $E$. coli by many examples such as production of geraniol and amorphadiene $[73,87]$. Single stranded mRNA easily forms secondary structures affecting the translational efficiency, which is worse in lengthy ploycistronic transcripts. CRISPR-based 
243 mRNA processing has been developed for physical separation of each cistron to minimize the

244 translational interference due to the formation of secondary structures of ploycistronic

245 transcripts [88]. An entire synthetic pathway can also be divided into several modules and the

246 modules are combinatorically combined and modulated to maximize the pathway efficiency,

247 which is called multivariate modular metabolic engineering (MMME) [89]. Besides, the

248 advance of Systems biology is helping us to mitigate bottleneck of the engineered pathway

249 and to understand the complex crosstalk that occurs between the pathway and the native

250 metabolic network. Targeted proteomics via selected-reaction monitoring (SRM) mass

251 spectrometry was used to optimize the amorphadiene synthetic pathway in E. coli [90]. A

252 computational tool termed as principal component analysis of proteomics (PCAP) was

253 consequently developed to mine a quantitative data set of targeted proteomics and to guide

254 metabolic engineering for production of limonene and bisabolene [91]. A recent report

255 described a workflow that integrates metabolomics, proteomics and genome-scale models of

256 E. coli metabolism to tailor the host to be suitable for biofuel production [92].

257 Living organisms have evolved bifunctional enzymes such as MvaE with dual roles of 258 acetoacetyl-CoA synthase and HMG-CoA reductase in the MVA pathway of Enterococcus 259 faecalis or organized consecutive enzymes of a metabolic pathway in a complex such as 260 pyruvate dehydrogenase complex to reduce intermediate accumulation and improve the 261 pathway efficiency [93,94]. Artificial fusion of FPP synthase and farnesene synthase 262 significantly improved farnesene production through the directed flow of IPP and DMAPP to 263 farnesene [67]. Artificial protein scaffolds could spatially organize pathway enzymes in a 264 desired stoichiometric ratio for optimal metabolic flux in the synthetic pathway. Organization 265 of the MVA pathway by protein scaffolds showed a great promise for mevalonate production 266 [95]. Beyond these static regulation approaches of gene expression, the application of 
267 biosensors opens up a new avenue to dynamic control of metabolic pathways and cellular 268 behaviors. Biosensors have been devised to positively or negatively respond to accumulation 269 of metabolites (Fig. 2b). FPP responsive promoter was screened by comparative 270 transcriptomics of E. coli with accumulation and no accumulation of FPP [96]. The FPP 271 responsive promoter-based biosensor could sense the FPP accumulation in cells, which is applied to dynamic regulation of expression of sesquiterpene synthases. The FPP biosensor showed a great advantage over the inducible trc promoter for amorphadiene production in $E$. coli by dynamic expressional regulation of amorphadiene synthase in response to FPP accumulation [96]. FadR-based dynamic sensor-regulation system (DSRS) was developed to sense fatty acyl-CoA, which thereby regulated biosynthesis of fatty acid ethyl ester [97]. Malonyl-CoA responsive FapR was rewired to dynamically control acetyl-CoA carboxylase and fatty acid synthase involved in malonyl-CoA generation and consumption, respectively [98].

Another important concern in construction of a synthetic pathway is substrate sterospecificities of the enzyme components. The inappropriate assembly of butanol synthetic pathway disregarding the substrate stereo-specificity of crotonases severely impaired the pathway efficiency, although crotonase homologs have similar kinetic behavior to their preferred 3-hydroxybutyl-CoA steroisomers [99].The inherent enzyme mechanism affords a powerful regulatory strategy called kinetic control element or driving forces to improve the efficiency of the entire pathway. The crotonyl-CoA reductase can serve as a regulatory valve to direct butanol synthesis $[29,99]$.

Tolerance engineering of $E$. coli host against biofuels

E. coli is a non-native biofuel strain from the viewpoint to $S$. cerevisiae and $C$. acetobutylicum naturally producing fuel-like ethanol and butanol. Thanks to advances in 
synthetic biology, E. coli can be drastically engineered to produce drop-in biofuels, while the accumulated organic solvents are generally toxic to E. coli cells. Many strains such as Psedumonas putida possess their own built-in tolerance mechanisms against toxic organic solvents, whereas $E$. coli is not competent to deal with toxicity of the biofuels produced in it. A prerequisite to create ideal $E$. coli host for biofuel production is the tolerance engineering and development of associated technologies (Fig. 3).

Living organisms employ various strategies against cytotoxicity of organic solvents, such as change of membrane composition, activation of stress response genes and expression of efflux pumps, which could be applied to manipulation of $E$. coli against toxic biofuels. Expression of Geobacillus sp. thioesterase, which primarily targets unsaturated medium chain length acyl-ACPs, restored a normal membrane lipids saturation level and improved tolerance towards high production of free fatty acids [100]. Overexpression of MarA involved in multiple antibiotic resistances could improve E. coli tolerance to geraniol [101], which was probably due to the MarA-mediated regulation of many stress responsible genes and ArcAB efflux pump. Engineering of efflux pump to expel biofuels out of cells would be the most promising strategy to improve host strain tolerance [102]. Several heterologous efflux pumps were evaluated to secrete terpenoid-based biofuels and found to improve biofuels yields

$308[103,104]$. The availability of outer membrane protein TolC to its inner membrane partners to

309 form tripartite efflux channel was elucidated to play an important role in the host tolerance to medium-chain $\left(\mathrm{C}_{4}-\mathrm{C}_{7}\right)$ alcohols [105]. Through knock-out of the major efflux pump AcrAB,

311 the increased TolC availability to the relevant inner membrane efflux pumps significantly

312 improved the E. coli tolerance to medium-chain alcohols including 1-butanol and isopentenol.

313 These rational approaches weigh on prior knowledges on regulator mechanism and efflux

314 pump preference; however, the advances in "Omics" technology provide a random approach 
315 to elucidate new tolerance mechanism and engineering rationales. It is possible to identify the 316 sense mutations accumulated in a long-term adaptive evolution and to intensify the

317 understanding of the physiological response network of cells to biofuels [106-108], which

318 would contribute to tolerance engineering of the host with desired phenotypes.

319 Transcription initiation factors, the so-called sigma factors, such as RpoD can regulate a set 320 of genes and change global metabolism to combat exotic stresses in E. coli [109]. Thus, the 321 engineering of the sigma factors, which is called global transcription machinery engineering 322 (gTME), offers another convenient and efficient method to improve host tolerance, because 323 the sophisticated works of tolerance manipulation can be simplified to the level of 324 engineering a single endogenous transcription factor. The error-prone RCR-based gTME has 325 been developed to improve E. coli tolerance to biofuels and exposed several potential 326 engineering targets for further strain improvements [110]. Biofuel tolerance is a complicated 327 multi-genic phenotype involving up-regulation of heat shock proteins, induction of efflux 328 pumps, modifications of cell membrane and envelope, modifications of energy generation and utilization, and other unknown tolerance mechanisms [111,112]. It is difficult to achieve

330 the enhanced biofuel tolerance traits without deep understanding of genetic, metabolic, and 331 physiological characteristics of host strains. Thus, the most of successful engineering work on 332 biofuel tolerance has been reported in E. coli.

\section{Conclusions}

334 During the past decade, a diverse array of natural and artificial biofuel synthesis pathways

335 have been demonstrated in the genetically tractable bacterium, E. coli. Given the speed with 336 which E. coli can be engineered, many demonstrations have advanced to near-commercial 337 levels of biofuel production. While many targets are not yet produced in sufficient quantities, 338 new synthetic and systems biology tools are enabling the creation of sophisticated regulatory 
339 and pathway assembly strategies. Similar efforts will be used to enhance other traits critical

340 to industrial biofuel synthesis. In our opinion, these endeavors will keep E. coli as a preferred 341 host when developing microbial cell factories for biofuel production 
343 This work was supported by C1 Gas Refinery Program through the NRF funded by the MSIP 344 (NRF-2016M3D3A1A01913246 / NRF-2015M3D3A1A01064882), and a grant (NRF345 2016M1A2A2924237) from the National Research Foundation, MSIP, Korea and the

346 Gyeongsang National University Fund for Professors on Sabbatical Leave, 2016. Wang C.

347 also thanked a project funded by the Priority Academic Program Development of Jiangsu

348 Higher Education Institutions (PAPD). Pfleger B. F. is supported by grants from the US

349 Department of Energy (DE-SC0010329), National Science Foundation (CBET 1149678;

350 EFRI-1240268), and the William F. Vilas Trust.

\section{Reference}

352 Articles of particular interest, published within the period of review, have been highlighted as:

$353 *$ of special interest

$354 * *$ of outstanding interest

1. Rude MA, Schirmer A: New microbial fuels: a biotech perspective. Curr Opin Microbiol 2009, 12:274-281.

2. Fortman JL, Chhabra S, Mukhopadhyay A, Chou H, Lee TS, Steen E, Keasling JD: Biofuel alternatives to ethanol: pumping the microbial well. Trends Biotechnol 2008, 26:375-381.

3. Dugar D, Stephanopoulos G: Relative potential of biosynthetic pathways for biofuels and bio-based products. Nat Biotechnol 2011, 29:1074-1078.

4. Huffer S, Roche CM, Blanch HW, Clark DS: Escherichia coli for biofuel production: bridging the gap from promise to practice. Trends Biotechnol 2012, 30:538-545. 
5. Ezeji TC, Qureshi N, Blaschek HP: Bioproduction of butanol from biomass: from genes to bioreactors. Curr Opin Biotechnol 2007, 18:220-227.

366

6. Alper H, Stephanopoulos G: Engineering for biofuels: exploiting innate microbial capacity or importing biosynthetic potential? Nat Rev Microbiol 2009, 7:715-723.

7. Atsumi S, Liao JC: Metabolic engineering for advanced biofuels production from Escherichia coli. Curr Opin Biotechnol 2008, 19:414-419.

8. Chen X, Zhou L, Tian K, Kumar A, Singh S, Prior BA, Wang Z: Metabolic engineering of Escherichia coli: a sustainable industrial platform for bio-based chemical production. Biotechnol Adv 2013, 31:1200-1223.

9. Bhan N, Xu P, Koffas MA: Pathway and protein engineering approaches to produce novel and commodity small molecules. Curr Opin Biotechnol 2013, 24:1137-1143.

10. Yadav VG, De Mey M, Lim CG, Ajikumar PK, Stephanopoulos G: The future of metabolic engineering and synthetic biology: towards a systematic practice. Metab Eng 2012, 14:233-241.

11. Merino ST, Cherry J: Progress and challenges in enzyme development for biomass utilization. Adv Biochem Eng Biotechnol 2007, 108:95-120.

12. Weng JK, Li X, Bonawitz ND, Chapple C: Emerging strategies of lignin engineering and degradation for cellulosic biofuel production. Curr Opin Biotechnol 2008, 19:166-172.

13. Ingram LO, Conway T, Alterthum F: Ethanol production by Escherichia coli strains co-expressing Zymomonas PDC and ADH genes. US Patent 1991.

14. Lee SK, Chou H, Ham TS, Lee TS, Keasling JD: Metabolic engineering of microorganisms for biofuels production: from bugs to synthetic biology to fuels. Curr Opin Biotechnol 2008, 19:556-563. 
15. Keasling JD, Chou $\mathrm{H}$ : Metabolic engineering delivers next-generation biofuels. Nat Biotechnol 2008, 26:298-299.

16. Zhang F, Rodriguez S, Keasling JD: Metabolic engineering of microbial pathways for advanced biofuels production. Curr Opin Biotechnol 2011, 22:775-783.

17. Wen M, Bond-Watts BB, Chang MC: Production of advanced biofuels in engineered $\boldsymbol{E}$. coli. Curr Opin Chem Biol 2013, 17:472-479.

18. Xue C, Zhao XQ, Liu CG, Chen LJ, Bai FW: Prospective and development of butanol as an advanced biofuel. Biotechnol Adv 2013, 31:1575-1584.

19. Atsumi S, Cann AF, Connor MR, Shen CR, Smith KM, Brynildsen MP, Chou KJ, Hanai T, Liao JC: Metabolic engineering of Escherichia coli for 1-butanol production. Metab Eng 2008, 10:305-311.

20. Inui M, Suda M, Kimura S, Yasuda K, Suzuki H, Toda H, Yamamoto S, Okino S, Suzuki N, Yukawa H: Expression of Clostridium acetobutylicum butanol synthetic genes in Escherichia coli. Appl Microbiol Biotechnol 2008, 77:1305-1316.

21. Nielsen DR, Leonard E, Yoon SH, Tseng HC, Yuan C, Prather KL: Engineering alternative butanol production platforms in heterologous bacteria. Metab Eng 2009, 11:262-273.

22. Hazelwood LA, Daran JM, van Maris AJ, Pronk JT, Dickinson JR: The Ehrlich pathway for fusel alcohol production: a century of research on Saccharomyces cerevisiae metabolism. Appl Environ Microbiol 2008, 74:2259-2266.

23. Atsumi S, Hanai T, Liao JC: Non-fermentative pathways for synthesis of branchedchain higher alcohols as biofuels. Nature 2008, 451:86-89.

24. Zhang K, Sawaya MR, Eisenberg DS, Liao JC: Expanding metabolism for biosynthesis of nonnatural alcohols. Proc Natl Acad Sci U S A 2008, 105:20653-20658. 
25. Marcheschi RJ, Li H, Zhang K, Noey EL, Kim S, Chaubey A, Houk KN, Liao JC: A synthetic recursive "+1" pathway for carbon chain elongation. ACS Chem Biol 2012, 7:689-697.

26. Rodriguez GM, Tashiro Y, Atsumi S: Expanding ester biosynthesis in Escherichia coli Nat Chem Biol 2014, 10:259-265.

27. Baez A, Cho KM, Liao JC: High-flux isobutanol production using engineered Escherichia coli: a bioreactor study with in situ product removal. Appl Microbiol Biotechnol 2011, 90:1681-1690.

28. Inokuma K, Liao JC, Okamoto M, Hanai T: Improvement of isopropanol production by metabolically engineered Escherichia coli using gas stripping. J Biosci Bioeng 2010, 110:696-701.

29. Shen CR, Lan EI, Dekishima Y, Baez A, Cho KM, Liao JC: Driving forces enable hightiter anaerobic 1-butanol synthesis in Escherichia coli. Appl Environ Microbiol 2011, 77:2905-2915.

30. Jang YS, Lee JY, Lee J, Park JH, Im JA, Eom MH, Lee J, Lee SH, Song H, Cho JH, et al.: Enhanced butanol production obtained by reinforcing the direct butanolforming route in Clostridium acetobutylicum. MBio 2012, 3.

31. Matsuda F, Ishii J, Kondo $\mathrm{T}$, Ida $\mathrm{K}$, Tezuka $\mathrm{H}$, Kondo A: Increased isobutanol production in Saccharomyces cerevisiae by eliminating competing pathways and resolving cofactor imbalance. Microb Cell Fact 2013, 12:119.

32. Blombach B, Riester T, Wieschalka S, Ziert C, Youn JW, Wendisch VF, Eikmanns BJ: Corynebacterium glutamicum tailored for efficient isobutanol production. Appl Environ Microbiol 2011, 77:3300-3310.

33. Qi H, Li S, Zhao S, Huang D, Xia M, Wen J: Model-driven redox pathway manipulation for improved isobutanol production in Bacillus subtilis 
complemented with experimental validation and metabolic profiling analysis. PLoS One 2014, 9:e93815.

34. Choi KY, Wernick DG, Tat CA, Liao JC: Consolidated conversion of protein waste into biofuels and ammonia using Bacillus subtilis. Metab Eng 2014, 23:53-61.

35. Park MO: New pathway for long-chain n-alkane synthesis via 1-alcohol in Vibrio furnissii M1. J Bacteriol 2005, 187:1426-1429.

36. Dennis MW, Kolattukudy PE: Alkane biosynthesis by decarbonylation of aldehyde catalyzed by a microsomal preparation from Botryococcus braunii. Arch Biochem Biophys 1991, 287:268-275.

37. Yu KO, Jung J, Kim SW, Park CH, Han SO: Synthesis of FAEEs from glycerol in engineered Saccharomyces cerevisiae using endogenously produced ethanol by heterologous expression of an unspecific bacterial acyltransferase. Biotechnol Bioeng 2012, 109:110-115.

*38. Fatma Z, Jawed K, Mattam AJ, Yazdani SS: Identification of long chain specific aldehyde reductase and its use in enhanced fatty alcohol production in E. coli. Metab Eng 2016, 37:35-45.

39. Jawed K, Mattam AJ, Fatma Z, Wajid S, Abdin MZ, Yazdani SS: Engineered production of short chain fatty acid in Escherichia coli using fatty acid synthesis pathway. PLoS One 2016, 11:e0160035.

40. Jing F, Cantu DC, Tvaruzkova J, Chipman JP, Nikolau BJ, Yandeau-Nelson MD, Reilly PJ: Phylogenetic and experimental characterization of an acyl-ACP thioesterase family reveals significant diversity in enzymatic specificity and activity. $B M C$ Biochem 2011, 12:44.

41. Kim S, Cheong S, Gonzalez R: Engineering Escherichia coli for the synthesis of shortand medium-chain $\boldsymbol{\alpha}, \boldsymbol{\beta}$-unsaturated carboxylic acids. Metab Eng 2016, 36:90-98. 
42. Jiang W, Jiang Y, Bentley GJ, Liu D, Xiao Y, Zhang F: Enhanced production of branched-chain fatty acids by replacing $\beta$-ketoacyl-(acyl-carrier-protein) synthase III (FabH). Biotechnol Bioeng 2015, 112:1613-1622.

43. Bentley GJ, Jiang W, Guaman LP, Xiao Y, Zhang F: Engineering Escherichia coli to produce branched-chain fatty acids in high percentages. Metab Eng 2016, 38:148158.

44. Dellomonaco C, Clomburg JM, Miller EN, Gonzalez R: Engineered reversal of the beta-oxidation cycle for the synthesis of fuels and chemicals. Nature 2011, 476:355-359.

*45. Cao YX, Xiao WH, Liu D, Zhang JL, Ding MZ, Yuan YJ: Biosynthesis of odd-chain fatty alcohols in Escherichia coli. Metab Eng 2015, 29:113-123.

46. Choi YJ, Lee SY: Microbial production of short-chain alkanes. Nature 2013, 502:571574.

47. Buijs NA, Zhou YJ, Siewers V, Nielsen J: Long-chain alkane production by the yeast Saccharomyces cerevisiae. Biotechnol Bioeng 2015, 112:1275-1279.

48. Feng X, Lian J, Zhao H: Metabolic engineering of Saccharomyces cerevisiae to improve 1-hexadecanol production. Metab Eng 2015, 27:10-19.

49. Zhu Q, Jackson EN: Metabolic engineering of Yarrowia lipolytica for industrial applications. Curr Opin Biotechnol 2015, 36:65-72.

50. Blazeck J, Hill A, Liu L, Knight R, Miller J, Pan A, Otoupal P, Alper HS: Harnessing Yarrowia lipolytica lipogenesis to create a platform for lipid and biofuel production. Nat Commun 2014, 5:3131.

51. Tai M, Stephanopoulos G: Engineering the push and pull of lipid biosynthesis in oleaginous yeast Yarrowia lipolytica for biofuel production. Metab Eng 2013, 15:19. 
52. Qiao K, Imam Abidi SH, Liu H, Zhang H, Chakraborty S, Watson N, Kumaran Ajikumar P, Stephanopoulos G: Engineering lipid overproduction in the oleaginous yeast Yarrowia lipolytica. Metab Eng 2015, 29:56-65.

53. Rutter CD, Rao CV: Production of 1-decanol by metabolically engineered Yarrowia lipolytica. Metab Eng 2016, 38:139-147.

54. Blazeck J, Liu L, Knight R, Alper HS: Heterologous production of pentane in the oleaginous yeast Yarrowia lipolytica. J Biotechnol 2013, 165:184-194.

55. Wang G, Xiong X, Ghogare R, Wang P, Meng Y, Chen S: Exploring fatty alcoholproducing capability of Yarrowia lipolytica. Biotechnol Biofuels 2016, 9:107.

56. $\mathrm{Xu} \mathrm{P}$, Qiao K, Ahn WS, Stephanopoulos G: Engineering Yarrowia lipolytica as a platform for synthesis of drop-in transportation fuels and oleochemicals. Proc Natl Acad Sci U S A 2016, 113:10848-10853.

57. Miziorko HM: Enzymes of the mevalonate pathway of isoprenoid biosynthesis. Arch Biochem Biophys 2011, 505:131-143.

58. Rohdich F, Kis K, Bacher A, Eisenreich W: The non-mevalonate pathway of isoprenoids: genes, enzymes and intermediates. Curr Opin Chem Biol 2001, 5:535540.

59. Withers ST, Gottlieb SS, Lieu B, Newman JD, Keasling JD: Identification of isopentenol biosynthetic genes from Bacillus subtilis by a screening method based on isoprenoid precursor toxicity. Appl Environ Microbiol 2007, 73:6277-6283.

60. Chou HH, Keasling JD: Synthetic pathway for production of five-carbon alcohols from isopentenyl diphosphate. Appl Environ Microbiol 2012, 78:7849-7855.

*61. George KW, Thompson MG, Kang A, Baidoo E, Wang G, Chan LJ, Adams PD, Petzold CJ, Keasling JD, Lee TS: Metabolic engineering for the high-yield production of isoprenoid-based $\mathbf{C}_{\mathbf{5}}$ alcohols in $\boldsymbol{E}$. coli. Sci Rep 2015, 5:11128. 
62. Zheng Y, Liu Q, Li L, Qin W, Yang J, Zhang H, Jiang X, Cheng T, Liu W, Xu X, et al.: Metabolic engineering of Escherichia coli for high-specificity production of isoprenol and prenol as next generation of biofuels. Biotechnol Biofuels 2013, 6:57. *63. Wang C, Park JE, Choi ES, Kim SW: Farnesol production in Escherichia coli through the construction of a farnesol biosynthesis pathway - application of PgpB and YbjG phosphatases. Biotechnol J 2016.

64. Ohto C, Muramatsu M, Obata S, Sakuradani E, Shimizu S: Overexpression of the gene encoding HMG-CoA reductase in Saccharomyces cerevisiae for production of prenyl alcohols. Appl Microbiol Biotechnol 2009, 82:837-845.

65. Sarria S, Wong B, Garcia Martin H, Keasling JD, Peralta-Yahya P: Microbial synthesis of pinene. ACS Synth Biol 2014, 3:466-475.

66. Zhou J, Wang C, Yoon SH, Jang HJ, Choi ES, Kim SW: Engineering Escherichia coli for selective geraniol production with minimized endogenous dehydrogenation. $J$ Biotechnol 2014, 169:42-50.

67. Wang C, Yoon SH, Jang HJ, Chung YR, Kim JY, Choi ES, Kim SW: Metabolic engineering of Escherichia coli for a-farnesene production. Metab Eng 2011, 13:648-655

68. Peralta-Yahya PP, Ouellet M, Chan R, Mukhopadhyay A, Keasling JD, Lee TS: Identification and microbial production of a terpene-based advanced biofuel. $\mathrm{Nat}$ Commun 2011, 2:483.

69. Alonso-Gutierrez J, Chan R, Batth TS, Adams PD, Keasling JD, Petzold CJ, Lee TS: Metabolic engineering of Escherichia coli for limonene and perillyl alcohol production. Metab Eng 2013, 19:33-41.

70. Whited GM, Feher FJ, Benko DA, Cervin MA, Chotani GK, McAuliffe JC, LaDuca RJ, Ben-Shoshan EA, Sanford KJ: Development of a gas-phase bioprocess for 
isoprene-monomer production using metabolic pathway engineering. Industrial Biotechnology 2010, 6:152-163.

71. Meadows AL, Hawkins KM, Tsegaye Y, Antipov E, Kim Y, Raetz L, Dahl RH, Tai A, Mahatdejkul-Meadows T, Xu L, et al.: Rewriting yeast central carbon metabolism for industrial isoprenoid production. Nature 2016, 537:694-697.

72. Pfleger BF, Pitera DJ, Smolke CD, Keasling JD: Combinatorial engineering of intergenic regions in operons tunes expression of multiple genes. Nat Biotechnol 2006, 24:1027-1032.

73. Nowroozi FF, Baidoo EE, Ermakov S, Redding-Johanson AM, Batth TS, Petzold CJ,

74. Zhang J, Jensen MK, Keasling JD: Development of biosensors and their application in metabolic engineering. Curr Opin Chem Biol 2015, 28:1-8.

75. Wang Z, Cirino PC: New and improved tools and methods for enhanced biosynthesis of natural products in microorganisms. Curr Opin Biotechnol 2016, 42:159-168.

**76. Jiang W, Bikard D, Cox D, Zhang F, Marraffini LA: RNA-guided editing of bacterial genomes using CRISPR-Cas systems. Nat Biotechnol 2013, 31:233-239.

**77. Qi LS, Larson MH, Gilbert LA, Doudna JA, Weissman JS, Arkin AP, Lim WA: Repurposing CRISPR as an RNA-guided platform for sequence-specific control of gene expression. Cell 2013, 152:1173-1183.

558 These two articles desribe CRISPR systems for genome editing and gen silencing. 559 
78. Bassalo MC, Garst AD, Halweg-Edwards AL, Grau WC, Domaille DW, Mutalik VK, Arkin AP, Gill RT: Rapid and efficient one-step metabolic pathway integration in E. coli. ACS Synth Biol 2016, 5:561-568.

79. Cress BF, Toparlak OD, Guleria S, Lebovich M, Stieglitz JT, Englaender JA, Jones JA, Linhardt RJ, Koffas MA: CRISPathBrick: modular combinatorial assembly of type II-A CRISPR arrays for dCas9-mediated multiplex transcriptional repression in E. coli. ACS Synth Biol 2015, 4:987-1000.

80. Kim SK, Han GH, Seong W, Kim H, Kim SW, Lee DH, Lee SG: CRISPR interferenceguided balancing of a biosynthetic mevalonate pathway increases terpenoid production. Metab Eng 2016, 38:228-240.

81. Lybecker M, Zimmermann B, Bilusic I, Tukhtubaeva N, Schroeder R: The doublestranded transcriptome of Escherichia coli. Proc Natl Acad Sci U S A 2014, 111:3134-3139.

82. Yang Y, Lin Y, Li L, Linhardt RJ, Yan Y: Regulating malonyl-CoA metabolism via synthetic antisense RNAs for enhanced biosynthesis of natural products. Metab Eng 2015, 29:217-226.

83. Aiba H: Mechanism of RNA silencing by Hfq-binding small RNAs. Curr Opin Microbiol 2007, 10:134-139.

84. Chae TU, Kim WJ, Choi S, Park SJ, Lee SY: Metabolic engineering of Escherichia coli for the production of 1,3-diaminopropane, a three carbon diamine. Sci Rep 2015, 5:13040.

85. Na D, Yoo SM, Chung H, Park H, Park JH, Lee SY: Metabolic engineering of Escherichia coli using synthetic small regulatory RNAs. Nat Biotechnol 2013, 31:170-174. 
86. Salis HM, Mirsky EA, Voigt CA: Automated design of synthetic ribosome binding sites to control protein expression. Nat Biotechnol 2009, 27:946-950.

87. Zhou J, Wang C, Yang L, Choi ES, Kim SW: Geranyl diphosphate synthase: an important regulation point in balancing a recombinant monoterpene pathway in Escherichia coli. Enzyme Microb Technol 2015, 68:50-55.

88. Qi L, Haurwitz RE, Shao W, Doudna JA, Arkin AP: RNA processing enables predictable programming of gene expression. Nat Biotechnol 2012, 30:1002-1006.

89. Biggs BW, De Paepe B, Santos CN, De Mey M, Kumaran Ajikumar P: Multivariate modular metabolic engineering for pathway and strain optimization. Curr Opin Biotechnol 2014, 29:156-162.

90. Redding-Johanson AM, Batth TS, Chan R, Krupa R, Szmidt HL, Adams PD, Keasling JD, Lee TS, Mukhopadhyay A, Petzold CJ: Targeted proteomics for metabolic pathway optimization: application to terpene production. Metab Eng 2011, 13:194-203.

91. Alonso-Gutierrez J, Kim EM, Batth TS, Cho N, Hu Q, Chan LJ, Petzold CJ, Hillson NJ, Adams PD, Keasling JD, et al.: Principal component analysis of proteomics (PCAP) as a tool to direct metabolic engineering. Metab Eng 2015, 28:123-133.

92. Brunk E, George KW, Alonso-Gutierrez J, Thompson M, Baidoo E, Wang G, Petzold CJ, McCloskey D, Monk J, Yang L, et al.: Characterizing strain variation in engineered $\boldsymbol{E}$. coli using a multi-omics-based workflow. Cell Syst 2016, 2:335-346.

93. Hedl M, Sutherlin A, Wilding EI, Mazzulla M, McDevitt D, Lane P, Burgner JW, 2nd, Lehnbeuter KR, Stauffacher CV, Gwynn MN, et al.: Enterococcus faecalis acetoacetyl-coenzyme A thiolase/3-hydroxy-3-methylglutaryl-coenzyme A reductase, a dual-function protein of isopentenyl diphosphate biosynthesis. $J$ Bacteriol 2002, 184:2116-2122. 
94. Izard T, Aevarsson A, Allen MD, Westphal AH, Perham RN, de Kok A, Hol WG: Principles of quasi-equivalence and Euclidean geometry govern the assembly of cubic and dodecahedral cores of pyruvate dehydrogenase complexes. Proc Natl Acad Sci U S A 1999, 96:1240-1245.

95. Dueber JE, Wu GC, Malmirchegini GR, Moon TS, Petzold CJ, Ullal AV, Prather KL, Keasling JD: Synthetic protein scaffolds provide modular control over metabolic flux. Nat Biotechnol 2009, 27:753-759.

96. Dahl RH, Zhang F, Alonso-Gutierrez J, Baidoo E, Batth TS, Redding-Johanson AM, Petzold CJ, Mukhopadhyay A, Lee TS, Adams PD, et al.: Engineering dynamic pathway regulation using stress-response promoters. Nat Biotechnol 2013, 31:1039-1046.

**97. Zhang F, Carothers JM, Keasling JD: Design of a dynamic sensor-regulator system for production of chemicals and fuels derived from fatty acids. Nat Biotechnol 2012, 30:354-359.

This alticle describes a dynamic sensor to the fattay acid flux.

98. Liu D, Xiao Y, Evans BS, Zhang F: Negative feedback regulation of fatty acid production based on a malonyl-CoA sensor-actuator. ACS Synth Biol 2015, 4:132140.

99. Bond-Watts BB, Bellerose RJ, Chang MC: Enzyme mechanism as a kinetic control element for designing synthetic biofuel pathways. Nat Chem Biol 2011, 7:222-227. 100. Lennen RM, Pfleger BF: Modulating membrane composition alters free fatty acid tolerance in Escherichia coli. PLoS One 2013, 8:e54031. 
101. Shah AA, Wang C, Chung YR, Kim JY, Choi ES, Kim SW: Enhancement of geraniol resistance of Escherichia coli by MarA overexpression. J Biosci Bioeng 2013, 115:253-258.

102. Jones CM, Hernandez Lozada NJ, Pfleger BF: Efflux systems in bacteria and their metabolic engineering applications. Appl Microbiol Biotechnol 2015, 99:9381-9393.

103. Lennen RM, Politz MG, Kruziki MA, Pfleger BF: Identification of transport proteins involved in free fatty acid efflux in Escherichia coli. J Bacteriol 2013, 195:135-144.

104. Dunlop MJ, Dossani ZY, Szmidt HL, Chu HC, Lee TS, Keasling JD, Hadi MZ, Mukhopadhyay A: Engineering microbial biofuel tolerance and export using efflux pumps. Mol Syst Biol 2011, 7:487.

*105. Wang C, Yang L, Shah AA, Choi ES, Kim SW: Dynamic interplay of multidrug transporters with TolC for isoprenol tolerance in Escherichia coli. Sci Rep 2015, 5:16505.

106. Si HM, Zhang F, Wu AN, Han RZ, Xu GC, Ni Y: DNA microarray of global transcription factor mutant reveals membrane-related proteins involved in $\boldsymbol{n}$ butanol tolerance in Escherichia coli Biotechnol Biofuels 2016, 9:114.

107. Brynildsen MP, Liao JC: An integrated network approach identifies the isobutanol response network of Escherichia coli. Mol Syst Biol 2009, 5:277.

108. Foo JL, Jensen HM, Dahl RH, George K, Keasling JD, Lee TS, Leong S, Mukhopadhyay A: Improving microbial biogasoline production in Escherichia coli using tolerance engineering. MBio 2014, 5:e01932.

109. Gao X, Jiang L, Zhu L, Xu Q, Xu X, Huang H: Tailoring of global transcription sigma D factor by random mutagenesis to improve Escherichia coli tolerance towards low-pHs. J Biotechnol 2016, 224:55-63. 
110. Zhang F, Qian X, Si H, Xu G, Han R, Ni Y: Significantly improved solvent tolerance of Escherichia coli by global transcription machinery engineering. Microb Cell Fact 2015, 14:175.

111. Nicolaou SA, Gaida SM, Papoutsakis ET: A comparative view of metabolite and substrate stress and tolerance in microbial bioprocessing: From biofuels and chemicals, to biocatalysis and bioremediation. Metab Eng 2010, 12:307-331.

112. Dunlop MJ: Engineering microbes for tolerance to next-generation biofuels. Biotechnol Biofuels 2011, 4:32.

113. Smith KM, Cho KM, Liao JC: Engineering Corynebacterium glutamicum for isobutanol production. Appl Microbiol Biotechnol 2010, 87:1045-1055.

114. Vogt M, Brusseler C, Ooyen JV, Bott M, Marienhagen J: Production of 2-methyl-1butanol and 3-methyl-1-butanol in engineered Corynebacterium glutamicum. Metab Eng 2016, 38:436-445.

115. Frohwitter J, Heider SA, Peters-Wendisch P, Beekwilder J, Wendisch VF: Production of the sesquiterpene (+)-valencene by metabolically engineered Corynebacterium glutamicum. J Biotechnol 2014, 191:205-213.

116. Mi J, Becher D, Lubuta P, Dany S, Tusch K, Schewe H, Buchhaupt M, Schrader J: De novo production of the monoterpenoid geranic acid by metabolically engineered Pseudomonas putida. Microb Cell Fact 2014, 13:170.

117. Yang X, Nambou K, Wei L, Hua Q: Heterologous production of $\boldsymbol{\alpha}$-farnesene in metabolically engineered strains of Yarrowia lipolytica. Bioresour Technol 2016, 216:1040-1048. 


\begin{tabular}{|c|c|c|c|c|c|}
\hline \multicolumn{6}{|c|}{ Comparison of Escherichia coli with other industrial strains for biofuel synthesis } \\
\hline \multirow{2}{*}{ Strains } & \multicolumn{3}{|c|}{ Biofuel types } & \multirow{2}{*}{$\begin{array}{l}\text { Available } \\
\text { genetic } \\
\text { tools }\end{array}$} & \multirow{2}{*}{ Biofuel tolerance } \\
\hline & Higher alcohols & Fatty acids & Terpenoids & & \\
\hline Escherichia coli & $\begin{array}{l}\text { - Non-native producer } \\
\text { - Engineered for production of } \\
\text { many higher alcohols } \\
\text { - Titer: } 143 \mathrm{~g} / \mathrm{L} \text { isopropanol } \\
\text { [27], } 50.9 \mathrm{~g} / \mathrm{L} \text { isobutanol[28], } \\
30 \mathrm{~g} / \mathrm{L} 1-\text { butanol [29], etc. }\end{array}$ & $\begin{array}{l}\text { - Non-native producer } \\
\text { - Engineered for production of } \\
\text { many fatty acid derivatives } \\
\text { - Titer: } 1.95 \mathrm{~g} / \mathrm{L} \text { fatty alcohols } \\
\text { [45], } 0.6 \mathrm{~g} / \mathrm{L} \text { fatty alkanes [46], } \\
1.1 \mathrm{~g} / \mathrm{L} \text { fatty ester [97], etc. }\end{array}$ & $\begin{array}{l}\text { - Non-native producer } \\
\text { - Engineered for production of } \\
\text { many terpenoids via MEP or } \\
\text { MVA pathway } \\
\text { - Titer: } 2.2 \mathrm{~g} / \mathrm{L} \text { isopentenol } \\
\text { [61], 0.53 g/L farnesol [63], } \\
\text { 1.1 g/L bisabolene [91], > } 60 \\
\text { g/L isoprene [69], etc. }\end{array}$ & Many & $\begin{array}{l}\text { - Low tolerance to most } \\
\text { biofuels } \\
\text { - Many studies on } \\
\text { tolerance engineering }\end{array}$ \\
\hline $\begin{array}{l}\text { Corynebacterium } \\
\text { glutamicum }\end{array}$ & $\begin{array}{l}\text { - Non-native producer } \\
\text { - Engineered for production of } \\
\text { few higher alcohols } \\
\text { - Titer: } 4.0 \mathrm{~g} / \mathrm{L} \text { isobutanol } \\
\text { [113], } 2.8 \mathrm{~g} / \mathrm{L} 3 \text {-methyl-1- } \\
\text { butanol, and 0.37 g/L 2- } \\
\text { methyl-1-butanol [114] }\end{array}$ & - Non-native producer & $\begin{array}{l}\text { - Non-native producer } \\
\text { - Engineered for valencene } \\
\text { production via MEP pathway } \\
\text { - Titer: } 2.4 \mathrm{mg} / \mathrm{L} \text { valencene } \\
\text { [115] }\end{array}$ & Not many & $\begin{array}{l}\text { - Not clear for biofuel } \\
\text { tolerance } \\
\text { - Few studies on } \\
\text { tolerance engineering }\end{array}$ \\
\hline $\begin{array}{c}\text { Saccharomyces } \\
\text { cerevisiae }\end{array}$ & $\begin{array}{l}\text { - Native ethanol producer } \\
\text { - Engineered for isobutanol } \\
\text { production } \\
\text { - Titer: } 1.62 \mathrm{~g} / \mathrm{L} \text { isobutantol } \\
\text { [31] }\end{array}$ & $\begin{array}{l}\text { - Non-native producer } \\
\text { - Engineered for production of } \\
\text { many fatty acid derivatives } \\
\text { - Titer: } 0.1 \mathrm{~g} / \mathrm{L} \text { fatty alkanes } \\
\text { [47], } 1.1 \mathrm{~g} / \mathrm{L} \text { hexadecanol [48], } \\
\text { etc. }\end{array}$ & $\begin{array}{l}\text { - Non-native producer } \\
\text { - Engineered for production of } \\
\text { many terpenoids via MVA } \\
\text { pathway } \\
\text { - Titer: } 0.1 \mathrm{~g} / \mathrm{L} \text { farnesol [64], } \\
1.0 \mathrm{~g} / \mathrm{L} \text { bisabolene [68], >100 } \\
\text { g/L farnesene [71], etc. }\end{array}$ & Many & $\begin{array}{l}\text { - High tolerance to } \\
\text { ethanol } \\
\text { - Not many studies on } \\
\text { tolerance engineering }\end{array}$ \\
\hline
\end{tabular}




\begin{tabular}{|c|c|c|c|c|c|}
\hline $\begin{array}{c}\text { Clostridium } \\
\text { acetobutylicum }\end{array}$ & $\begin{array}{l}\text { - Native butanol producer } \\
\text { - Engineered for high butanol } \\
\text { production } \\
\text { - Titer: } 130 \mathrm{~g} / \mathrm{L} \text { butanol [30] }\end{array}$ & - Non-native producer & - Non-native producer & Few & $\begin{array}{l}\text { - High tolerance to } \\
\text { butanol } \\
\text { - Not many studies on } \\
\text { tolerance engineering }\end{array}$ \\
\hline $\begin{array}{l}\text { Pseudomonas } \\
\text { putida }\end{array}$ & $\begin{array}{l}\text { - Non-native producer } \\
\text { - Engineered for butanol } \\
\text { production } \\
\text { - Titer range: } 0.12 \mathrm{~g} / \mathrm{L} \text { butanol } \\
\text { [21] }\end{array}$ & - Non-native producer & $\begin{array}{l}\text { - Non-native producer } \\
\text { - Engineered for geranic acid } \\
\text { production via MVA pathway } \\
\text { - Titer: } 0.19 \mathrm{~g} / \mathrm{L} \text { geranic acid } \\
\text { [116] }\end{array}$ & Not many & $\begin{array}{l}\text { - High tolerance to } \\
\text { many organic solvents } \\
\text { - Few studies on } \\
\text { tolerance engineering }\end{array}$ \\
\hline Bacillus subtilis & $\begin{array}{l}\text { - Non-native producer } \\
\text { - Engineered for production of } \\
\text { few higher alcohols } \\
\text { - Titer: } 24 \mathrm{mg} / \mathrm{L} \text { butanol [21] } \\
\text { and } 6.1 \mathrm{~g} / \mathrm{L} \text { isobutanol [33] }\end{array}$ & - Non-native producer & $\begin{array}{l}\text { - Native isoprene producer } \\
\text { - Engineered for isoprene } \\
\text { production via MEP pathway }\end{array}$ & Not many & $\begin{array}{l}\text { - Not clear for biofuel } \\
\text { tolerance } \\
\text { - No study on tolerance } \\
\text { engineering }\end{array}$ \\
\hline Yarrowia lipolytica & - Non-native producer & $\begin{array}{l}\text { - Native producer } \\
\text { - Engineered for production of } \\
\text { fatty acid derivatives } \\
\text { - Titer: } 0.5 \mathrm{~g} / \mathrm{L} \text { decanol [53], } \\
4.98 \mathrm{mg} / \mathrm{L} \text { pentane [54], and } \\
0.64 \mathrm{~g} / \mathrm{L} \text { hexadecanol [55] }\end{array}$ & $\begin{array}{l}\text { - Non-native producer } \\
\text { - Engineered for } \alpha \text {-farnesene } \\
\text { production via MVA pathway } \\
\text { - Titer: } 0.26 \mathrm{~g} / \mathrm{L} \alpha \text {-farnesene } \\
\text { [117] }\end{array}$ & Not many & $\begin{array}{l}\text { - Not clear for biofuel } \\
\text { tolerance } \\
\text { - No study on tolerance } \\
\text { engineering }\end{array}$ \\
\hline
\end{tabular}


Enzymes involved in metabolic engineering of E. coli for biofuel synthesis

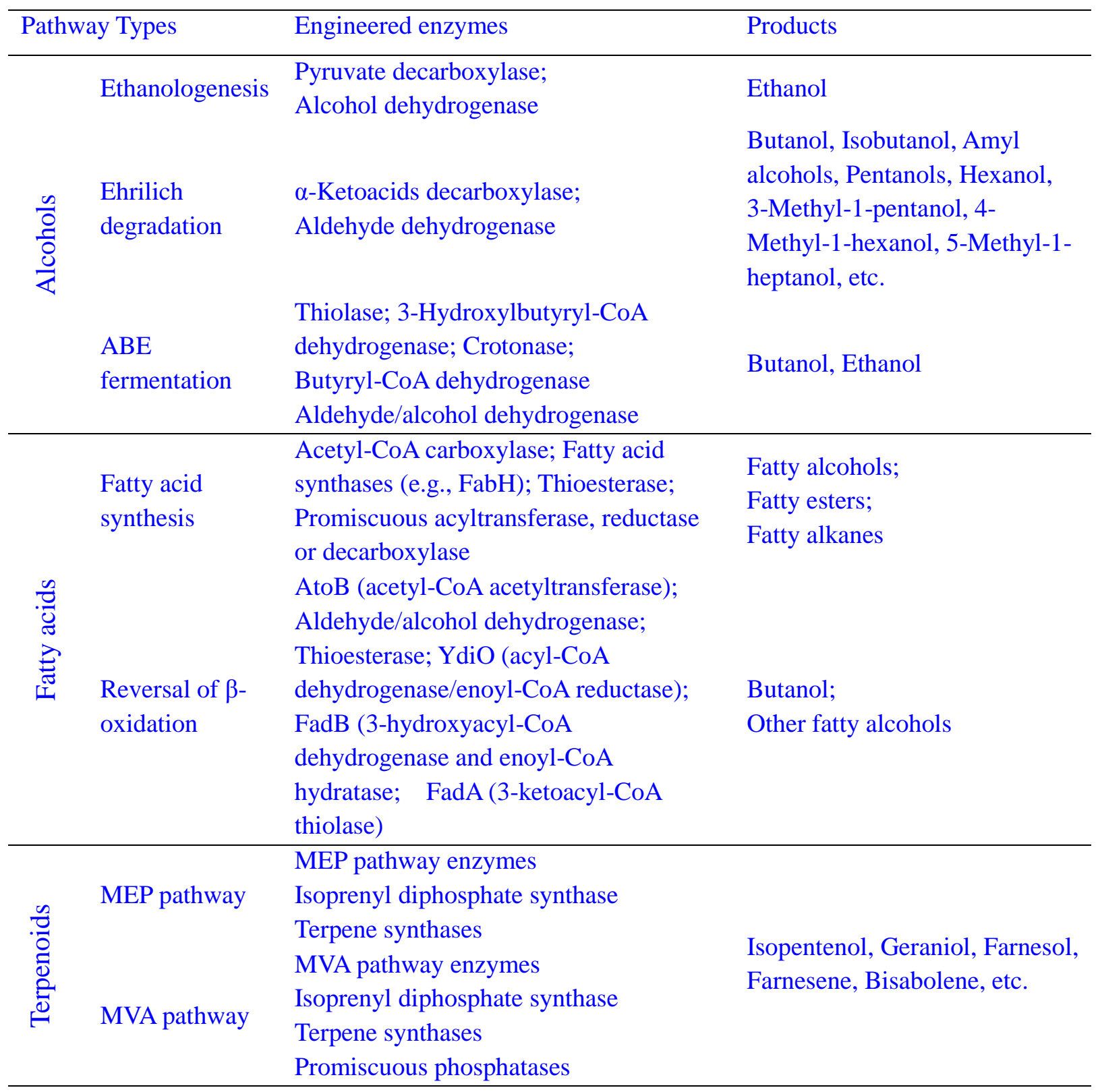




\section{Figure legends}

683 Figure 1. Scheme of engineered metabolic pathways to produce candidate biofuels in $E$.

684 coli. Introduction of the heterologous metabolic pathways (black arrows) enables 685 recombinant $E$. coli to synthesize various candidate biofuels from the central metabolites 686 (gray arrows) of E. coli. These candidates were categorized into three types: high alcohols, 687 fatty acids and terpenoids.

688 Figure 2. Schemes of CRISPR technology for gene editing and silencing (a), and 689 biosensor modes for pathway regulation (b).

690 Figure 3. Engineering schemes of efflux pump and transcription factor for tolerance

691 improvement. Introduction of biofuel synthesis pathway (pBiofuel) in E. coli leads to the 692 accumulation of biofuel products, which would cause cytotoxicity in the host cell (upper 693 panel). An engineered efflux pump transports the biofuel products out of cell to reduce the 694 toxicity, and an engineering of transcription factor can regulate global gene expression of the 695 host to improve the biofuel tolerance (upper panel). In a native biofuel producer (lower panel), 696 the tolerance engineering has been restricted due to a limited information on efflux pump and 697 transcription factor of the host.

698 


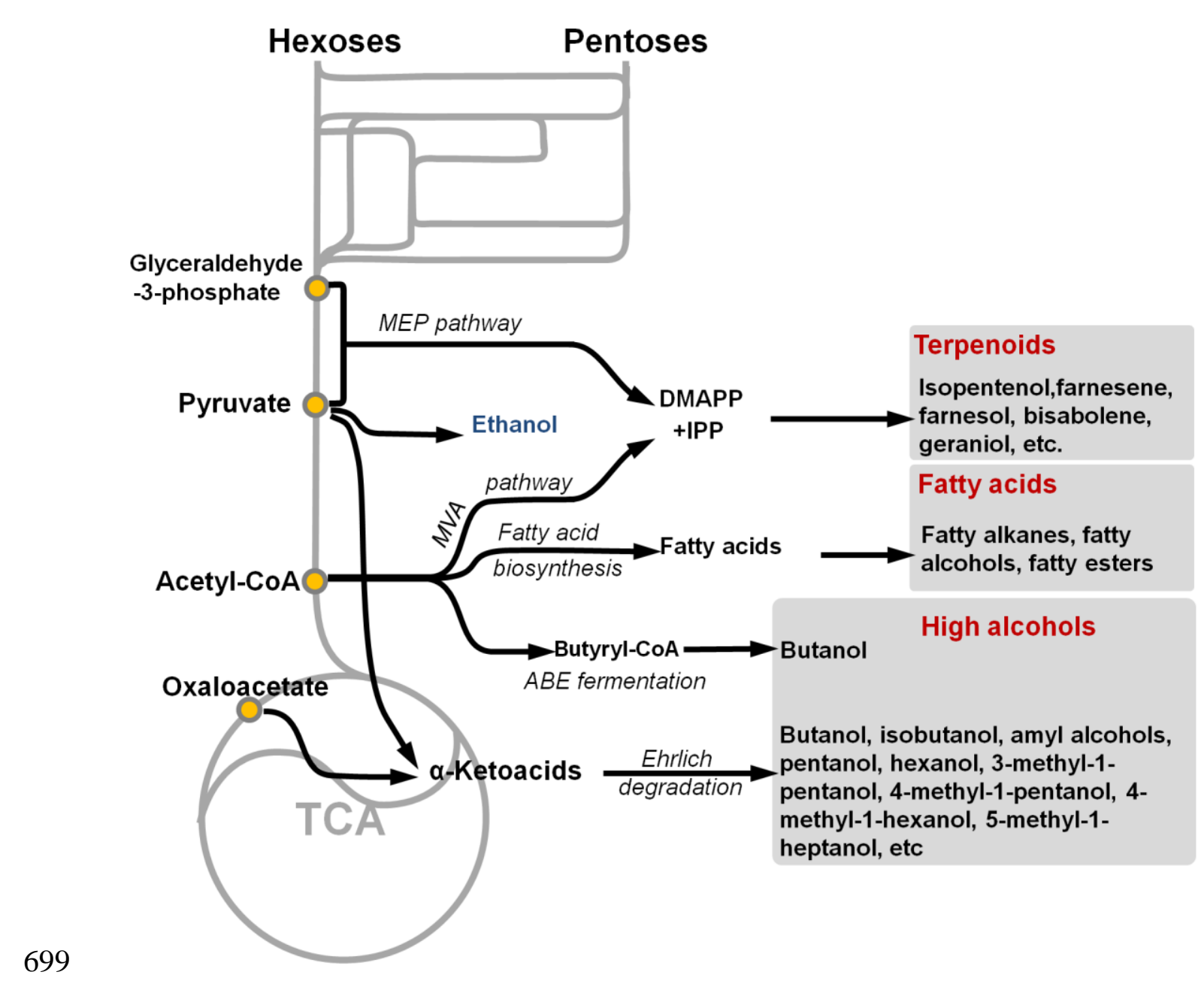


(a)
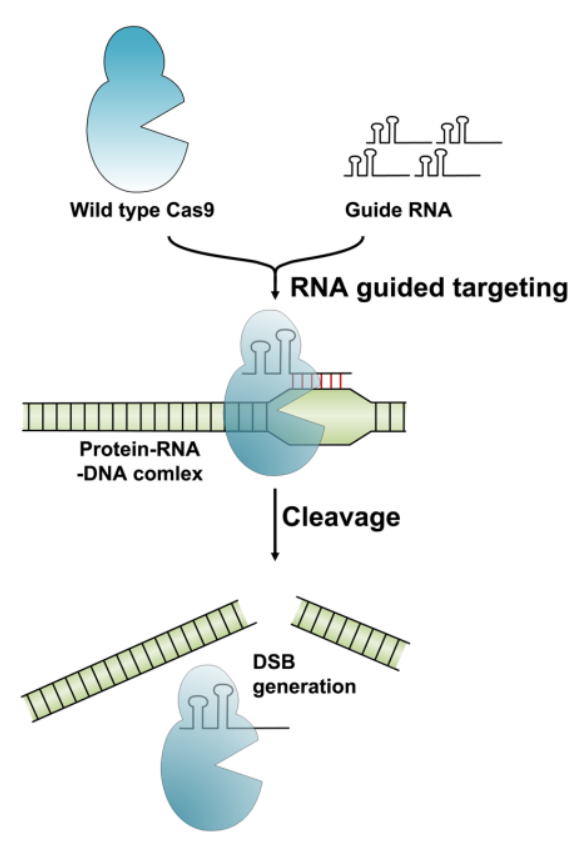

CRISPR editing

(b)
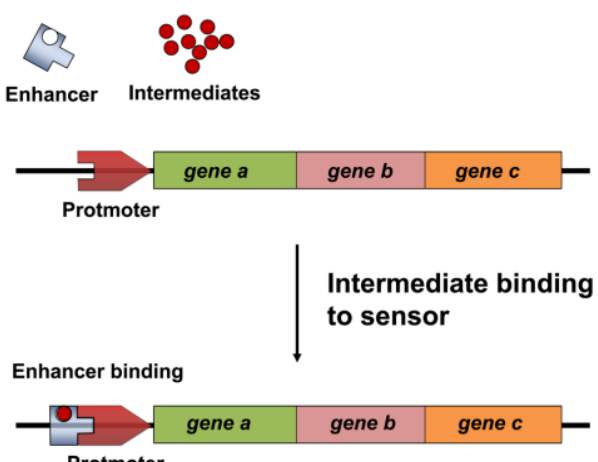

Protmoter
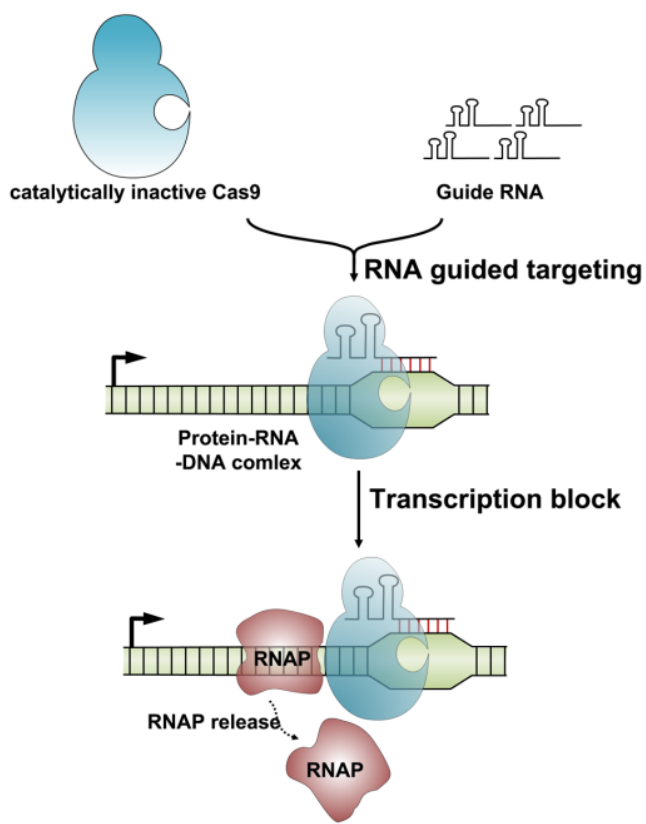

CRISPR interference 


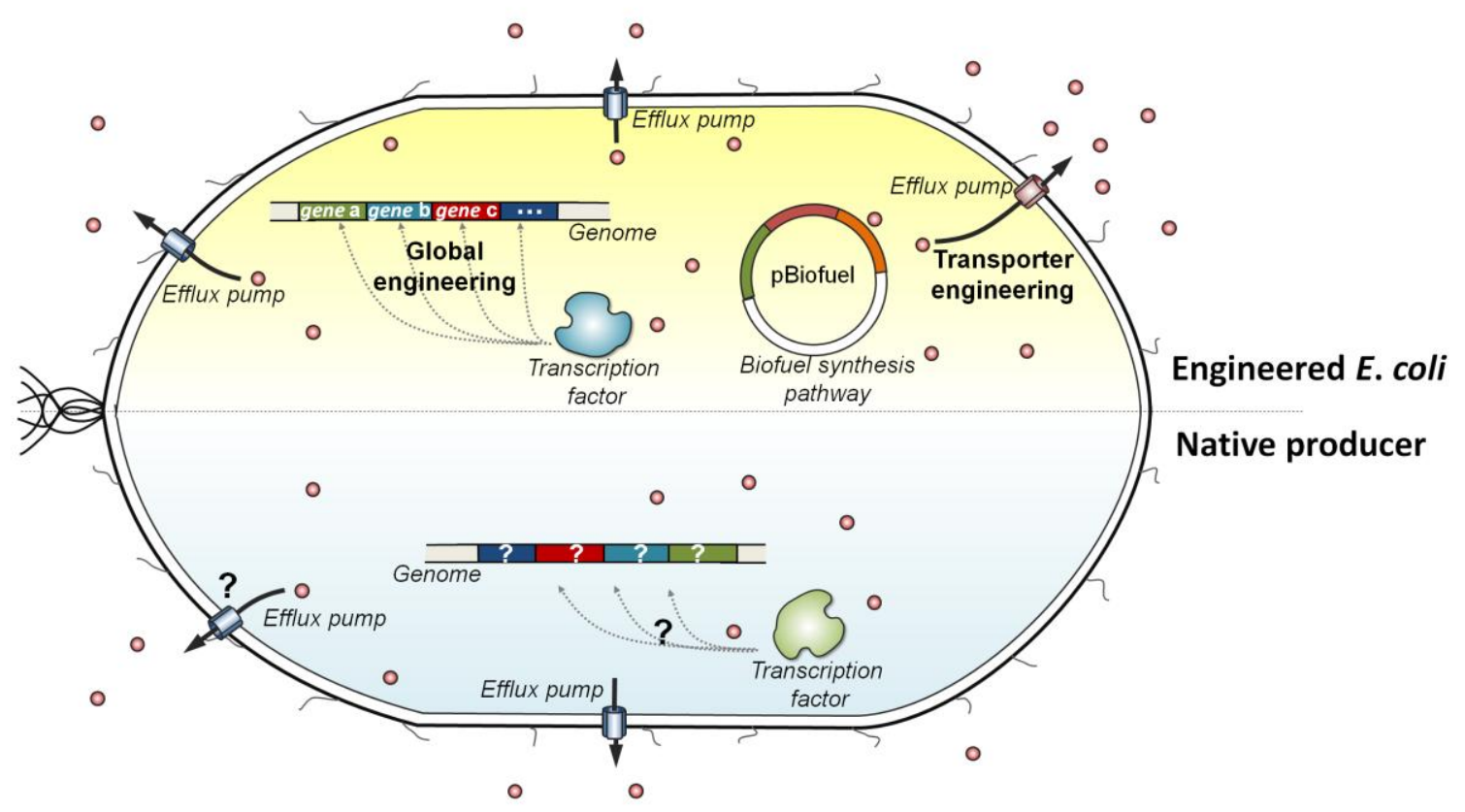

